Pesq. Vet. Bras. 37(10):1091-1100, outubro 2017 DOI: $10.1590 / \mathrm{S} 0100-736 \mathrm{X} 2017001000009$

\title{
Anatomopathological pneumonic aspects associated with highly pathogenic Pasteurella multocida in finishing pigs ${ }^{1}$
}

\author{
Eliana S. Paladino², Michelle de P. Gabardo², Priscilla N. Lunardi², Nelson Morés ${ }^{3}$ \\ and Roberto M.C. Guedes ${ }^{2 *}$
}

\begin{abstract}
Paladino E.S., Gabardo M.P., Lunardi P.N., Morés N. \& Guedes R.M.C. 2017. Anatomopathological pneumonic aspects associated with highly pathogenic Pasteurella multocida in finishing pigs. Pesquisa Veterinária Brasileira 37(10):1091-1100. Departamento de Clinica e Cirurgia Veterinária, Escola de Veterinária, Universidade Federal de Minas Gerais (UFMG), Av. Antônio Carlos 6627, Belo Horizonte, MG 31270-901, Brazil. E-mail: guedesufmg@gmail.com

The bacterium Pasteurella multocida is a frequent cause of porcine respiratory disease complex in finishing pigs. Historically, the bacterium is recognized as an opportunistic agent, causing secondary bacterial pneumonia in pigs. Several Brazilian reports have suggested the ability of $P$. multocida to cause primary pulmonary infection that leads to the death of finishing pigs prior to slaughter. The aim of this study was to evaluate anatomopathological pulmonary findings associated with $P$. multocida infection that were obtained from animals with clinical respiratory disease and from animals at slaughter. Twenty-five lung samples from 14 herds of finishing pigs with acute clinical respiratory disease and 19 lungs collected at slaughter from a different set of 14 herds were studied. In all lung samples, bacterial isolation was performed, and only samples with pure P. multocida growth were included in the study. Gross and histopathological lesions were evaluated, as well as Influenza A, porcine circovirus type 2 (PCV2) and Mycoplasma hyopneumoniae co-infections. Pleuritis and pericarditis were more often observed in clinical samples $(P<0.05)$. Moreover, there was a numerical trend indicating that pericarditis, lymphadenomegaly and cavity exudates were more often present in clinical samples. Thirteen lung samples were negative to M. hyopneumoniae, Influenza A and PCV2 by immunohistochemistry (IHC), with only $P$. multocida identified. In these cases, gross lesions such as pleuritis, pericarditis and lymphadenomegaly were always present, and no histologic lesions indicative of other agents such as Actinobacillus pleuropneumoniae, Actinobacillus suis or Haemophilus parasuis were observed. These findings suggest the ability of some $P$. multocida isolates to cause primary respiratory and systemic infection. However, in this study, it was not possible to determine specific virulence markers to explain these findings.
\end{abstract}

INDEX TERMS: Pasteurella multocida, pneumonia, swine, pasteurellosis, pleuropneumonia, fibrin.

RESUMO--[Aspectospneumônicosanatomo-patológicos associados a Pasteurella multocida de alta patogenicidade em suínos de terminação.] A bactéria Pasteurella multocida é causa frequente do Complexo de Doenças Res-

\footnotetext{
${ }^{1}$ Received on April 1, 2017.

Accepted for publication on May 15, 2017.

${ }^{2}$ Departamento de Clinica e Cirurgia Veterinária, Escola de Veterinária, Universidade Federal de Minas Gerais (UFMG), Av. Antônio Carlos 6627, Belo Horizonte, MG 31270-901, Brazil. * Corresponding author: guedesufmg@gmail.com

${ }^{3}$ Embrapa Suinos e Aves, Rodovia BR-153 Km 110, Cx. Postal 21, Distrito de Tamandua, Concordia, SC 89700-000, Brazil.
}

piratórias dos suínos em animais de terminação. Historicamente, a bactéria é reconhecida como agente oportunista, causando pneumonia bacteriana secundária. Diversos relatos brasileiros sugerem a habilidade da P. multocida de causar infecção pulmonar primária que leva a mortalidade de animais de terminação antes do abate. 0 objetivo deste estudo foi avaliar achados anatomopatológicos pulmonares associados com infecção por P. multocida, obtidas de animais acometidos clinicamente por doença respiratória e de animais ao abate. Avaliou-se 25 amostras de pulmão de 14 rebanhos obtidas de animais de terminação com sinais clínicos de doença respiratória aguda, e 19 pulmões coletados 
ao abate de 14 rebanhos diferentes. Em todos os pulmões, realizou-se isolamento bacteriano, e apenas amostras com crescimento puro de $P$. multocida foram incluídas no trabalho. Avaliou-se as lesões macro e microscopicamente, assim como co-infecções por Influenza A, Circovirus suíno tipo 2 (PCV2) e Mycoplasma hyopneumoniae. Pleurite e pericardite foram mais frequentemente observadas em amostras clinicas $(P<0,05)$. Ainda, houve tendência numérica indicando a ocorrência de linfadenomegalia e exsudação cavitária, mais presentes em amostras clínicas. Treze amostras de pulmão foram negativas para $M$. hyopneumoniae, Influenza A e PCV2 por imunoistoquímica (IHQ), com identificação de apenas P. multocida. Nestes casos, lesões macroscópicas como pleurite, pericardite e linfadenomegalia foram sempre presentes, sem lesões histológicas indicativas de outros agentes como Actinobacillus pleuropneumoniae, Actinobacillus suis ou Haemophilus parasuis. Estes achados sugerem a habilidade de alguns isolados de P. multocida de causarem quadro respiratório primário e infecção sistêmica. No entanto, neste estudo, não foi possível determinar marcadores de virulência específicos para justificar tais achados.

TERMOS DE INDEXAÇÃO: Pasteurella multocida, pneumonia, pasteurelose, pleuropneumonia, fibrina.

\section{INTRODUCTION}

Respiratory disorders are one of the most important problems in the modern pig industry due to economic losses caused by mortality, reduced growth rate and carcass condemnation at slaughter. Porcine respiratory disease complex (PRDC) is a multifactorial syndrome that affects growing and finishing pigs worldwide. In Brazil, the protagonist agents of PRDC are Mycoplasma hyopneumoniae, porcine Circovirus type 2 (PCV2) (Castro 2008, Souza et al. 2008, Costa et al. 2009, Heres 2009, Kich et al. 2010), Influenza A virus, H1N1 endemic and pandemic and H3N2 subtypes (Brentano et al. 2002, Mancini et al. 2006, Schaefer et al. 2011, Morés et al. 2015), and secondary bacterial infections. PRRS virus is exotic in Brazil. Pasteurella multocida (P. multocida) appears as the most common bacterial agent in PRDC related to pleuropneumonia cases (Morés 2006, Hansen et al. 2010, Fablet et al. 2011, Morés et al. 2015).

Historically, $P$. multocida is considered to be a secondary infection, aggravating pulmonary infections caused by M. hyopneumoniae and PCV2 (Kim et al. 2003, Pijoan 2006, Hansen et al. 2010, Wellenberg et al. 2010, Fablet et al. 2011, Pors et al. 2011, 2013). However, researchers in southern Brazil (Borowski 2001, Morés 2006, Borowski et al. 2007, Kich et al. 2007, 2010, Morés et al. 2015, Oliveira Filho 2015) and Argentina (Cappuccio et al. 2004) have suggested that $P$. multocida is a primary agent capable of causing severe respiratory disease, nevertheless its pathogenesis and invasiveness mechanisms are not clearly described yet. These cases were grossly similar to the pleuropneumonia caused by Actinobacillus pleuropneumoniae and fibrinous pericarditis and pleuritis due to Haemophilus parasuis, and also resembles Fowl cholera, consequently causing mortality in growing and finishing pigs. These re- ports suggest that highly pathogenic strains of P. multocida, capable of causing pneumonic lesions typical of A. pleuropneumoniae and/or H. parasuis, are circulating in Brazilian swine herds, especially in the most significant production regions, such as the states of Santa Catarina, Rio Grande do Sul, Paraná, Minas Gerais, São Paulo and Mato Grosso.

This study aimed to evaluate the occurrence of highly pathogenic field P. multocida in farms with history of high mortality rates in finishing pigs associated with fibrinous pleuropneumonia, to characterize the histopathological lesions and to evaluate the occurrence of co-infections and the susceptibility of the isolated P. multocida to the commonly used antimicrobials in the swine industry. In addition, these findings were compared to samples obtained from animals considered clinically healthy by the Slaughterhouse Inspection System prior to slaughter but that demonstrated severe bronchopneumonia lesions.

\section{MATERIALS AND METHODS}

Ethics statement. The study was approved by the Ethics Committee for Animal Experimentation of the Universidade Federal de Minas Gerais (UFMG CETEA, Approval \# 111/11), and conducted at the same institution.

Study design and sampling. One to three lungs were collected from 28 different herds consisting of two categories of samples: clinical samples obtained at the farm (Group A, 14 farms) and samples obtained at the slaughterhouse (Group B, 14 farms). In total, 44 lungs were assessed: twenty-five clinical samples (Group A) were obtained from farms with a history of severe respiratory disease affecting animals in the finishing phase and that were associated with high mortality rates, and 19 samples were collected (one to three lungs per batch) in a slaughterhouse (Group B) located in the metropolitan region of Belo Horizonte, Minas Gerais, Brazil.

The inclusion criterion for lung samples in this study was the isolation of only P. multocida by bacteriology, thus, samples with mixed or no bacterial isolation were not included. Animals selected for clinical sampling (Group A) were euthanized at the farm and fragments of lungs, heart, trachea and lymph nodes were collected during the post-mortem evaluation. When exudate was present in the thoracic or pericardial cavities, sterile swabs were used for sampling. All samples from Groups A and B were immediately chilled for submission to the laboratory and upon arrival, all samples were evaluated and classified based on the type of gross lesions. The extent and distribution of the lung consolidated areas and the presence of necrosis, the hemorrhagic events and the abscesses were described. The affected lung area was evaluated according to Halbur et al. (1995) (Fig.1). In addition, the pleural evaluation described the general appearance, thickness, color and deposition of exudate, and the mediastinal lymph nodes were evaluated based on color and size and were classified as normal, mildly, moderately or severely enlarged. The evaluation of the heart was based on the presence of lesions in the epicardial and pericardial sacs, the exudate accumulation within the pericardial sac, and the presence of a fibrous adhesion between the parietal and visceral leaflets.

Bacterial culture and inoculum. Two regions of each lung with consolidation were selected in addition to pleural and/or epicardial samples in cases of cavitary effusion. Lung samples were inoculated by imprinting a fragment in a Casman Agar Base (BD BBL ${ }^{\mathrm{TM}}$, Franklin Lakes, Nova Jersey, EUA) plate supplemented with 5\% defibrinated sheep blood (ASA) and in a MacConkey Agar 

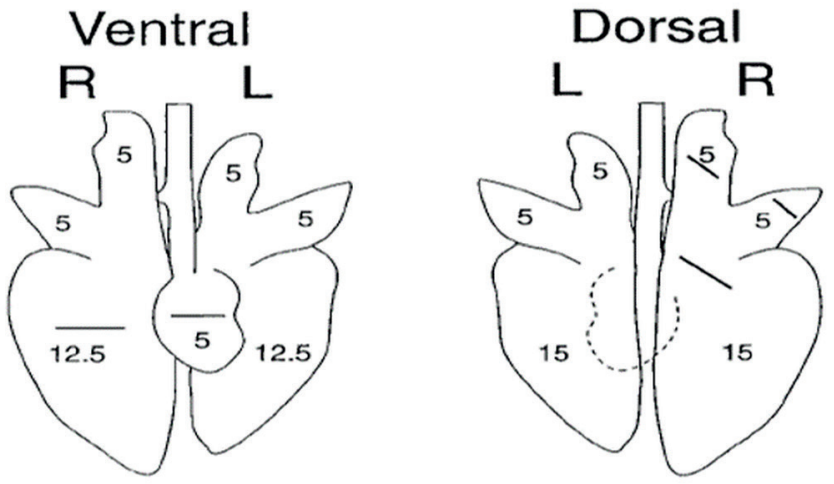

Fig.1. Schematic representation of lung gross evaluation method, where each lobe receives a score based on the affected area extension, totalling 100 points, according to Halbur et al. (1995). ( $\mathrm{R}=$ right side, $\mathrm{L}=$ left side).

plate (MCK) (BD DIFCO ${ }^{\mathrm{TM}}$, Franklin Lakes, Nova Jersey, EUA). After inoculation in the ASA, a single line of Staphylococcus aureus was spread across the plate to produce the V-factor. Plates were incubated in a microaerophilic environment at $37^{\circ}$ Celsius and evaluated after 36 and 60 hours of incubation. The colonies were evaluated for morphology, and biochemical tests, and Gram staining was performed as described by Quinn et al. (1994). When $P$. multocida growth was confirmed, phenotypic tests for hyaluronidase (Carter \& Rundell 1975) and acriflavine (Carter \& Subronto 1973) were performed to determine the capsular subtypes A and $D$, respectively. All isolates were tested for the presence of the toxA gene by PCR according to Lichtensteiger et al. (1996) and Townsend et al. (2001).

Histopathology. Mediastinal lymph nodes and fragments of $2 \mathrm{~cm}^{3}$ of each lung sample were collected for histopathology, selected from areas with visible lesions, such as consolidation, abscesses and pleuritis. Fragments of heart tissue were also collected but only those with gross lesions such as pericarditis. These fragments were fixed for 72 hours in $10 \%$ buffered formalin solution and subsequently processed by routine paraffin embedding techniques followed by microtomy and haematoxylin and eosin staining (Luna 1968). All samples were examined in an optical microscope following previously standardized criteria for histological description.

Immunohistochemistry (IHC) for Mycoplasma hyopneumoniae, PCV2 and Influenza A antigens were performed in all samples. Lung sections of $3 \mu \mathrm{m}$ on silanized slides were stained using the labelled streptavidin method (Dako LSAB, Glostrup, Denmark) with amino-ethyl-carbazole (AEC) (Dako, Glostrup, Denmark) as the chromogen. For PCV2 IHC, preference was given to lymph nodes, but lungs were also stained using a rabbit polyclonal antibody anti-PCV2 diluted 1:800 (Souza et al. 2008). Samples were considered positive when the cytoplasm and nucleus of lymphocytes and histiocytes were labelled. For the Influenza A virus, fragments of lungs and trachea were sampled using monoclonal antibody anti-Influenza A (anti-nucleoprotein clones A1, A3 Blend) diluted 1: 1000 according to Haines et al. (1993) and Vincent et al. (1997). Samples were considered positive when the cytoplasm of epithelial cells of bronchi, bronchioles and peribronchial glands stained red, as well as epithelial cells lining the trachea and its submucosal glands. In all tested batches, positive and negative controls were used.

IHC for the detection of Pasteurella multocida was performed using a monospecific polyclonal recombinant antibody against protein lactate dehydrogenase - p36 (Castro et al. 2009).
The protocol was standardized by the streptavidin-biotin-peroxidase method with a commercial kit (LSAB Kit ${ }^{\circledR}$ System - HRP - DakoCytomation ${ }^{\circledR}$, Glostrup, Denmark). Antigen retrieval was performed by the immersion of slides in citrate buffer ( $\mathrm{pH}$ 6.0) and heat treatment in a domestic microwave oven for five minutes at $700 \mathrm{~W}$. Subsequently, enzymatic digestion was performed using diluted $0.04 \%$ pepsin in hydrochloric acid $0.01 \mathrm{~N}(\mathrm{pH} 7.8$ ) for 10 minutes at $37^{\circ} \mathrm{C}$. Tissue sections were stained with primary antibody (anti-p36) for 2 hours at $37^{\circ} \mathrm{C}$ at a 1: 1000 dilution. The final staining was performed with an AEC solution for five minutes at $37^{\circ} \mathrm{C}$ followed by counterstaining with Mayer's haematoxylin for two minutes. Positive marks were observed in red on the airway epithelia and were classified according to intensity as mild (+), moderate $(++)$ and severe $(+++)$.

Antimicrobial sensitivity. All P. multocida isolates were tested for sensitivity to 15 different antimicrobials after enrichment in brain-heart-infusion broth (BHI) (BACTOTM BD, Franklin Lakes, Nova Jersey, EUA) by the disc diffusion technique according to Bauer et al. (1966). The selection of drugs was based on extensive use in the field, and included the following: amoxicillin $(10 \mathrm{mg})$, ceftiofur $(30 \mu \mathrm{g})$, ciprofloxacin $(5 \mu \mathrm{g})$, doxycycline $(30 \mu \mathrm{g})$, enrofloxacin $(5 \mu \mathrm{g})$, spectinomycin $(100 \mu \mathrm{g})$, florfenicol $(30 \mu \mathrm{g})$, gentamicin $(10 \mathrm{mg})$, lincomycin $(10 \mathrm{mg})$, norfloxacin $(10 \mathrm{mg})$, penicillin G $(10 \mathrm{U})$, sulfonamide $(25 \mu \mathrm{g})$, tetracycline $(30 \mu \mathrm{g})$, tiamulin $(30 \mu \mathrm{g})$ and tilmicosin $(15 \mu \mathrm{g})$. The evaluation of the sensitivity zones was performed according to the manufacturer's instructions, and the zones were classified as sensitive, partially sensitive and resistant. Partially sensitive samples were considered as resistant.

Statistical analysis. The statistical analysis to assess the frequency of gross and microscopic lesions and the distribution of results between Groups A and B was performed using Fisher's exact test according to the sample size. All analyses were performed by Statistix Software version 10.0 with a significance level of $95 \%(P<0.05)$. The extent of the sampled pneumonic areas in Groups A and B was evaluated by the nonparametric Mann-Whitney test with a significance level of 95\% $(P<0.05)$ for the medians.

\section{RESULTS}

Pasteurella multocida was isolated from the 44 lungs, and also four pleura, two pericardium cases and two exudate fluids present in the thoracic cavity, comprising 48 isolates in total. P. multocida type A was the most frequently obtained isolate $(40 / 44,90.9 \%)$, and type D was found in the remaining four samples $(4 / 44,9.1 \%)$, derived from two different herds of Group B (slaughter samples). The toxA gene was detected by PCR in only two clinical samples (Group A), both from the same herd.

Detailed grossly lesions can be analyzed in Table 1, but summarizing the most frequently observed lesion was bronchopneumonia with cranioventral areas of consolidation observed in 43 of 44 (97.7\%) lungs. All lungs from Group B had pneumonic lesions affecting from 8 to $80 \%$ of the lung with a median of $40 \%$, which was lower than Group A (Farm samples) $(P=0.0408)$, which had a median of $55 \%$, varying from 20 to $90 \%$ of the lung in animals between 90 and 170 days of age. Pleuritis and pericarditis were more frequently observed in group A $(P=0.0048$ and $P=0.02$ respectively). Three samples were characterized as mixed because there were areas in the early stages of chronicity, with fibrous adhesion between the affected visceral 
Table 1. Distribution of gross lesions of pigs with severe respiratory clinical condition (Group A) and pigs sampled in slaughterhouses (Group B)

\begin{tabular}{|c|c|c|c|c|c|}
\hline \multirow[b]{2}{*}{ Lesion } & \multicolumn{2}{|r|}{$\begin{array}{c}\text { Group A } \\
n=25\end{array}$} & \multicolumn{2}{|r|}{$\begin{array}{c}\text { Group B } \\
n=19\end{array}$} & \multirow[t]{2}{*}{$\mathrm{P}$} \\
\hline & $\mathrm{n}$ & $\begin{array}{l}\text { With bacterial } \\
\text { isolation }\end{array}$ & $\mathrm{n}$ & $\begin{array}{l}\text { No bacterial } \\
\text { isolation }\end{array}$ & \\
\hline Cranioventral Pneumonia & 24 & 24 & 19 & 19 & NA \\
\hline Pneumonia $^{a}$ Extension (median) & $55 \%$ & 24 & $40 \%$ & 19 & 0.0408 \\
\hline Catarrhal secretion & 25 & 25 & 19 & 19 & \\
\hline Pleuritis: & 13 & & 2 & & 0.0048 \\
\hline Acute & 2 & & 2 & & \\
\hline Fibrinous & 6 & 4 & 0 & & \\
\hline Chronic & 2 & & 0 & & \\
\hline Mixed & 3 & & 0 & & \\
\hline Pericarditis: & 9 & & 1 & & 0.02 \\
\hline Acute & 2 & 1 & 0 & & \\
\hline Fibrinous & 2 & 1 & 0 & & \\
\hline Chronic & 5 & & 1 & 1 & \\
\hline Lung Abscesses & $4^{\mathrm{a}}$ & NA & $3 a$ & NA & 1 \\
\hline Haemorrhage & $4^{\mathrm{a}}$ & NA & $1 \mathrm{a}$ & NA & 0.37 \\
\hline Cavitary liquid & $2^{\mathrm{a}}$ & 2 & $0 \mathrm{a}$ & & 0.49 \\
\hline Lymphadenomegaly $^{\mathrm{b}}$ & $18^{\mathrm{a}}$ & NA & $6 a$ & NA & $\begin{array}{c}0.12 \\
N=44\end{array}$ \\
\hline
\end{tabular}

${ }^{a}$ Calculation of pneumonia extent according to Halbur et al. (1995), demonstrated by the median value, ${ }^{\mathrm{b}}$ Moderate to intense enlargement of lymph nodes: $\mathrm{n}=33$ - by limitations at the time of collection; $\mathrm{NA}=$ not applicable. In bold, samples tested statistically different $(\mathrm{P}<0.05)$ from samples of group A and B in the same line.

pleura and adjacent tissues. The isolation of P. multocida was also possible in pleura from four cases from Group A where fibrinous pleuritis could be observed, and one was recovered from the pericardial sac lesion, in Group B. The mediastinal lymph nodes were evaluated in only 33 cases from the 44 animals, due to limitations during sampling. Twenty-four lymph nodes $(24 / 33,72.7 \%)$ were moderately to severely enlarged, which was interpreted as reactive, but there was no significant difference between groups.

One single animal from Group A had severe clinical respiratory signs characterized by severe dyspnea and cyanosis. At necropsy, this animal had severe acute diffuse fibrinous pleuritis and pericarditis associated with multifocal areas of adhesion between the parietal and visceral pleuras and extrapulmonary abscesses adjacent to the pleura and pericardium, with adhesion of all these tissues associated with purulent material accumulated in the pleural cavity. In this case, $P$. multocida was isolated from the lungs, pleura, pericardium, abscesses and free purulent exudate in the thoracic cavity, despite the absence of lesions suggestive of pneumonia on gross evaluation. Still, this animal showed fibrin exudation in the abdominal cavity, with fibrin deposition on spleen, liver and intestinal serosa, but no bacterial isolation was obtained from these locations.

Histopathological evaluation of the lungs (Table 2) revealed suppurative bronchopneumonia in 34 animals (34/44, $77.2 \%)$, characterized by an inflammatory reaction consisting predominantly of neutrophils in alveolar spaces and in the lumen of the bronchi and bronchioles. Eight samples from Group A $(8 / 44,18.2 \%)$ had a mixed pattern of pneumonia, bronchointerstitial pneumonia or interstitial lymph-histiocytic pneumonia, and in another fragment of the same sample, neutrophilic bronchopneumonia was observed, with the latter always prevailing. Additionally, two
Table 2. Distribution of pulmonary and pleural histopathological lesions collected from pigs with a severe respiratory clinical condition (group $A$ ) and in slaughterhouses (group B)

\begin{tabular}{|c|c|c|c|}
\hline & $\begin{array}{c}\text { Group A } \\
(n=25)\end{array}$ & $\begin{array}{c}\text { Group B } \\
(n=19)\end{array}$ & $\mathrm{P}$ \\
\hline Lesion & $\mathrm{n}$ & $\mathrm{n}$ & \\
\hline Pneumonia: & 25 & 19 & \\
\hline Suppurative & 16 & 18 & 0.0271 \\
\hline \multicolumn{4}{|l|}{ Bronchopneumonia } \\
\hline Bronchointerstitial & 1 & 1 & \\
\hline Mixed pattern & 8 & & \\
\hline Course: & & & 1.0000 \\
\hline Acute or Subacute: & 23 & 18 & \\
\hline Edema & 20 & 18 & \\
\hline Fibrin & 18 & 15 & \\
\hline Haemorrhage & 9 & 10 & \\
\hline Chronic: & 2 & 1 & 1.0000 \\
\hline \multicolumn{4}{|l|}{ Air ways: } \\
\hline Bronchitis/bronchiolitis ${ }^{a}$ & 17 & 13 & 1.0000 \\
\hline BALT b $(++)$ & 4 & 11 & 0.0089 \\
\hline Bronchiectasis & 8 & 3 & 0.3006 \\
\hline \multicolumn{4}{|l|}{ Pleura: } \\
\hline Pleuritis: & 12 & 6 & 0.3586 \\
\hline Acute pleuritis & 5 & & \\
\hline Fibrinous & 2 & & \\
\hline Chronic pleuritis & 5 & 6 & \\
\hline Haemorrhage & & 2 & \\
\hline Lymphadenopathy ${ }^{c}$ & 9 & 4 & 1.0000 \\
\hline Suppurative Lymphadenitis & 9 & 4 & \\
\hline Fibrin & 1 & 0 & \\
\hline Haemorrhage & 2 & 6 & 0.0082 \\
\hline Lymphoid depletion & 0 & 0 & \\
\hline Histiocytic infiltration & 0 & 0 & \\
\hline
\end{tabular}

a Moderate to severe bronchitis/bronchiolitis, ${ }^{\mathrm{b}}$ Moderate broncho-associated lymphoid tissue hyperplasia; no severe hyperplasia was observed, ${ }^{\mathrm{c}}$ Only 33 mediastinal lymph nodes were evaluated. In bold, samples tested statistically different $(\mathrm{P}<0.05)$ from samples of group $A$ and $B$ in the same line. 
cases $(2 / 44,4.5 \%)$ had only bronchointerstitial pneumonia, one from each group, characterized by inflammatory infiltration around the bronchi and bronchioles and alveolar wall but with no airway involvement. In these cases, the inflammatory infiltrate was predominantly mononuclear, with lymphocyte and plasma cell infiltration and mild BALT hyperplasia in both cases. Only mild to moderate Broncho-associated lymphoid tissue (BALT) hyperplasia occurred, more frequently in Group B $(P=0.0089)$, and severe cases were not observed.

In the lumen of the alveoli and in the interlobular spaces, remarkable circulatory disorders were observed such as the presence of hyaline and homogeneous material, suggesting edema, fibrin exudation and hemorrhage, placing these samples in the acute or sub-acute phases. In three of the samples $(3 / 44,6.8 \%)$, no remarkable circulatory lesions were observed, however, there was fibroblast proliferation in the alveoli and interlobular spaces associated with multifocal areas of necrosis in the alveoli and airways, suggesting chronicity in these cases. There was a specific characterization of the inflammatory process of the airways, with inflammatory infiltration around the bronchi and bronchioles, in the lamina propria and around the peribronchial glands. Moderate to severe lymphocytic-plasmacytic bronchitis and bronchiolitis was observed in 30 cases $(30 / 44,68.2 \%)$ with no significant difference between groups. Bronchiectasis was characterized by extensive bronchial necrosis associated with hemorrhage and large amounts of fibrin deposition, degenerated neutrophils and bacterial clumps associated with remarkable circulatory disorders in the alveoli, and it was observed in 11 samples, predominantly in Group A but not statistically different between groups.

Pleuritis was observed in 18 cases $(18 / 44,40.9 \%)$, characterized by lymphohistiocytic inflammatory infiltration predominantly in the visceral pleura, with no significant differences between groups (Table 2). Eleven lung samples $(11 / 44,25 \%)$ had chronic lesions characterized by marked proliferation of fibroblasts. In Group A, acute pleuritis was observed at varying degrees in seven cases, where two were fibrinous. Massive neutrophilic infiltration was observed in thirteen lymph nodes $(13 / 33,39.4 \%)$, characterized as moderate to severe acute neutrophilic lymphadenitis. In five of these $(5 / 33,15.1 \%)$ hemorrhaging was present, and in a single sample (Group A), neutrophilic fibrin-hemorrhagic lymphadenitis was observed. All of these samples had moderate to severe lymphadenomegaly based on macroscopic evaluation, and nine of them were from Group A. In three samples belonging to Group B (3/33, 9.1\%), only moderate to severe subcapsular hemorrhage was observed. There was no significant difference $(P>0.05)$ between groups for lymph node lesions. None showed lymphoid depletion and/or histiocytic infiltration (Table 2).

\section{Immunohistochemistry}

Twenty samples were positive for Influenza A virus $(20 / 44,45.5 \%)$. Of these, 18 presented mild to severe lympho-histioplasmocytic bronchitis and six had bronchiectasis. Twenty-three samples were positive for Mycoplasma hyopneumoniae $(23 / 44,52.3 \%)$, eight with mild labelling $(+)$, ten with moderate labelling $(++)$ and five with intense labelling $(+++), 15$ of these samples had mild to moderate BALT hyperplasia. No samples were positive to PCV2. Table 3 summarizes IHC results to histopathological findings.

\section{Cases with single Pasteurella multocida detection}

Bacteriological investigation revealed pure growth of P. multocida in thirteen samples $(13 / 44,29.5 \%)$ and negative results by IHC for the three investigated agents $(M$. hyopneumoniae, Influenza A virus and PCV2). Of these, seven were from Group A and six were collected at slaughter (Group B), and the characterization is summarized in Table 3. Each sample was derived from a different herd, and in six of these herds, the lungs of other animals sampled showed positive results for the other pathogens tested by IHC. Fibrin exudation was observed only in samples of Group A, and in the histological evaluation of the thirteen lungs, twelve had neutrophilic bronchopneumonia in the acute or subacute phase, with the presence of edema and fibrin in the alveolar and interlobular spaces in eleven

Table 3. Pulmonary histopathological lesions related to mixed infections of Pasteurella multocida and Mycoplasma hyopneumoniae, or Pasteurella multocida and Influenza type A, the three agents simultaneously or only Pasteurella multocida in lung samples from pigs with a severe respiratory clinical condition (group A) and slaughtered pigs (group B)

\begin{tabular}{|c|c|c|c|c|c|}
\hline Immunohistochemistry & $\mathrm{n}$ & $\begin{array}{c}\text { BALT } \\
\text { Hyperplasia }^{a}\end{array}$ & Bronchiectasis & Bronchitis $^{\mathrm{b}}$ & $\begin{array}{r}\text { Suppur } \\
\text { broncho-pn }\end{array}$ \\
\hline \multicolumn{6}{|l|}{ M. hyopneumoniae only } \\
\hline Group A & 7 & 4 & 1 & 4 & \\
\hline Group B & 4 & 2 & 0 & 1 & \\
\hline \multicolumn{6}{|c|}{ M. hyopneumoniae + Influenza A } \\
\hline Group A & 5 & 2 & 2 & 3 & \\
\hline Group B & 7 & 7 & 2 & 6 & \\
\hline \multicolumn{6}{|l|}{ Influenza A only } \\
\hline Group A & 6 & 2 & 2 & 6 & \\
\hline Group B & 2 & 1 & 0 & 2 & \\
\hline \multicolumn{6}{|l|}{ Pasteurella multocida only } \\
\hline Group A & 7 & 1 & 3 & 4 & \\
\hline Group B & 6 & 5 & 1 & 4 & \\
\hline
\end{tabular}

${ }^{\mathrm{a}}$ BALT $=$ mild to moderate broncho-associated lymphoid tissue hyperplasia, ${ }^{\mathrm{b}}$ Moderate to severe lympho-histioplasmocytic bronchitis/bronchiolitis. 
cases. Bronchiectasis occurred in four samples, three of them from Group A. BALT hyperplasia with mild intensity occurred in five samples of Group B and in one sample from Group A.

The mediastinal lymph node evaluation of clinical samples was possible only in six cases, and only a farm clinical sample had significant histological lesions, characterized by an acute to moderate fibrin-hemorrhagic neutrophilic lymphadenitis.

\section{Bacterial antimicrobial susceptibility}

The antimicrobial sensitivity evaluation of 44 lung isolates to 15 drugs is shown in Figure 2. Ceftiofur had the highest sensitivity ratio, followed by spectinomycin and florfenicol. The drugs with lower susceptibility rates were lincomycin, followed by penicillin and gentamicin. In Group A, one isolate was sensitive to only three of the 15 tested, and another one was sensitive to only five drugs. An isolate of Group B was sensitive to only four drugs. Twenty-five isolates showed resistance to between five and 12 drugs. One isolate from Group A and two from Group B were sensitive to fourteen drugs.

Figure 3 shows the sensitivity profile of Group A and Group B isolates. There was a significant difference in antimicrobial susceptibility between strains from the two

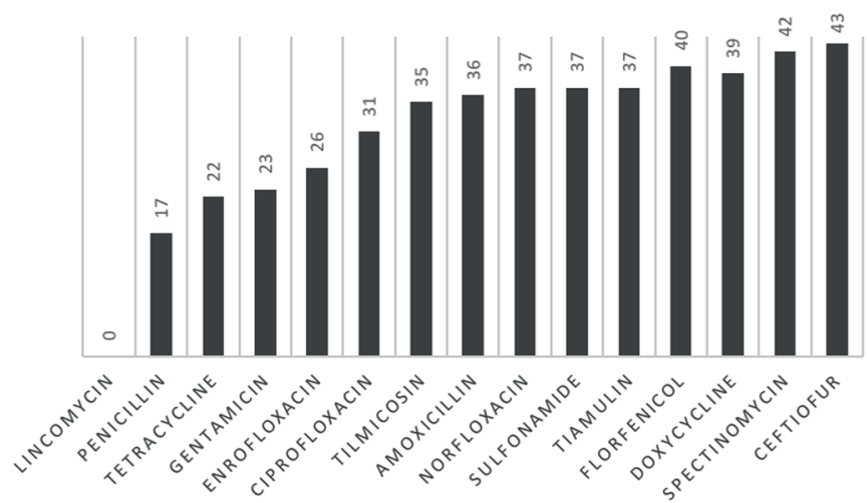

Fig.2. Antimicrobial susceptibility to fifteen antimicrobial drugs tested against 44 strains of Pasteurella multocida obtained from lungs of swine.

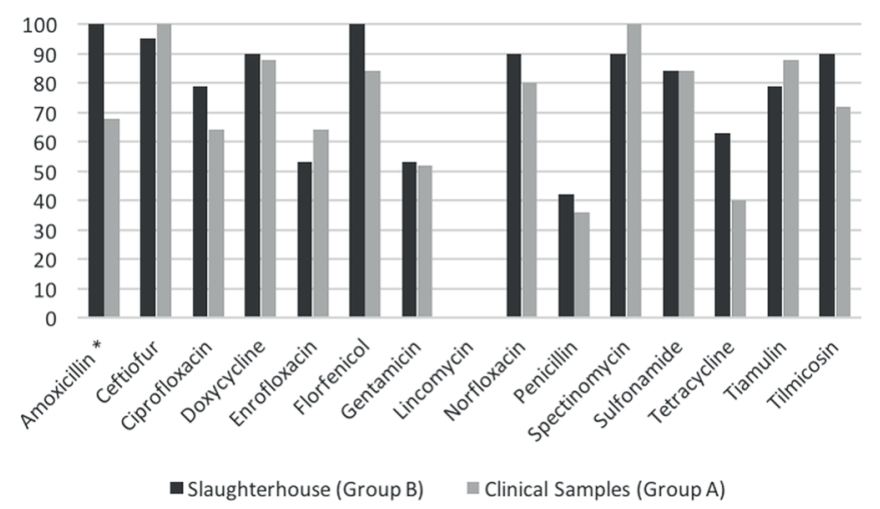

Fig.3. Percentage of sensitive isolates from each of 15 antimicrobials tested compared with isolates of Pasteurella multocida from group A and B. *Statistically significant difference $(\mathrm{P}<0.05)$ between samples from group $\mathrm{A}$ and $\mathrm{B}$.

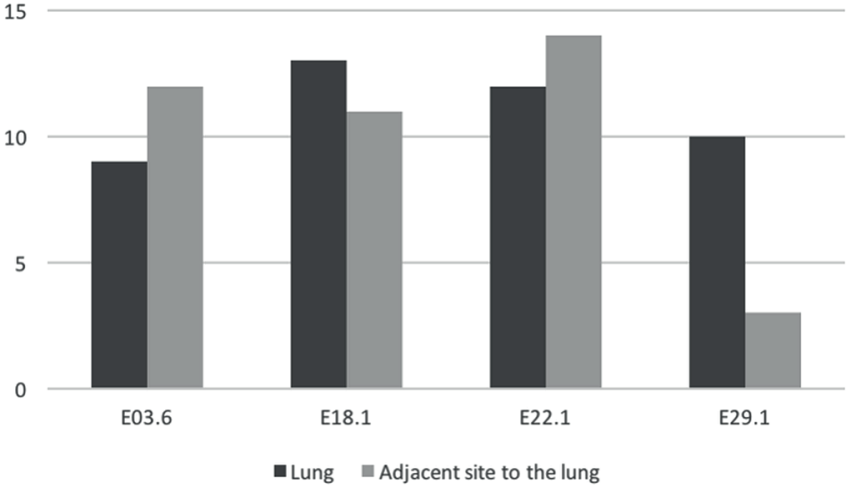

Fig.4. Comparison of sensitivity profile of Pasteurella multocida isolates obtained from the lung and extrapulmonary region in four different samples compared with 15 antimicrobial drugs. *Statistically significant difference $(\mathrm{P}<0.05)$ between isolated lungs and extrapulmonary region of each case.

Groups in the case of Amoxicillin $(P<0.05)$, however, there was a trend towards a higher resistance rate in strains isolated from Group A. The sensitivity profile of the four isolates recovered from extrapulmonary regions, from the pleura $(n=2)$ and the thoracic cavity $(n=1)$ of Group $A$ and from the pericardium $(n=1)$ from Group $B$, is shown in Figure 4 , where the results were compared to the sensitivity profile of the isolates of lungs, in each correlated sample.

\section{DISCUSSION}

Pasteurella multocida is an agent of major importance within the PRDC, and several Brazilian studies (Borowski 2001, Morés 2006, Borowski et al. 2007, Kich et al. 2007, Heres 2009, Oliveira Filho et al. 2015, Morés et al. 2015) and international studies (Kim et al. 2003, Ono et al. 2003, Cappuccio et al. 2004, Pijoan 2006, Hansen et al. 2010, Wellenberg et al. 2010, Pors et al. 2011, 2013, 2016) have reported its role. In this study, the involvement of $P$. multocida with severe respiratory disease in finishing pigs was evaluated, confirming the co-infection of this agent with Influenza type A virus and $M$. hyopneumoniae but not with PCV2. Furthermore, cases with only P. multocida involvement were identified, reinforcing previous reports of the existence of pleurotropic highly pathogenic strains with a primary role in the induction of lesions in the respiratory tract (Cappuccio et al. 2004, Kich et al. 2007, Pors et al. 2011, Oliveira Filho et al. 2015, Pors et al. 2016).

Brazilian studies have reported the involvement of highly pathogenic $P$. multocida in respiratory infections in the mortality of finishing pigs in Santa Catarina (Morés 2006) and Rio Grande do Sul (Borowski et al. 2002, Heres 2009), and Oliveira Filho et al. (2015) succeeded in experimentally reproducing the infection with a field isolate. However, no scientific reports describing this clinical picture were identified, and the only reports that suggest the association of $P$. multocida related to finishing pig mortality in the Brazilian main swine production regions - southeast and midwest were published in Conference proceedings (Barbosa et al. 2009, Silva et al. 2009, Maciel et al. 2011).

The results from the present study showed mass parti- 
cipation of serotype A in the pleuropneumonia cases. These data are consistent with literature reports of a higher participation of serotype A in pneumonic cases (Borowski 2001, Davies et al. 2003, Pijoan 2006, Borowski et al. 2007, Bethe et al. 2009, Boyce et al. 2010, Morés et al. 2015) and corroborate the data of Heres (2009). However, Morés (2006) found a higher frequency of serotype $D(27.3 \%)$ compared to serotype A (24\%) in samples obtained in slaughterhouses. In addition, the tox $A$ gene, which encodes the dermonecrotic toxin, was detected only in two clinical samples originating from the same herd. The importance of this toxin in swine pleuropneumonia is questionable (Pijoan 2006, Borowski et al. 2007, Boyce et al. 2010) since other studies have reported the absence of this gene in isolates obtained from porcine lung samples (Borowski et al. 2002, Heres 2009, Hansen et al. 2010, Costa et al. 2011), as was also observed in this study.

The pathologic evaluation of the samples revealed the expected type of alterations, in agreement with the literature (Pijoan 2006, Caswell \& Williams 2007). Clinical samples (Group A) showed more extent pneumonia $(P=0.0408)$, as well as a higher occurrence of pleuritis $(P=0.0048)$ and pericarditis $(P=0.02)$. Out of the fifteen samples with pleuritis, nine had fibrin deposition and ten had pericarditis simultaneously, two with severe fibrin accumulation. These findings contradict the literature (Pijoan 2006, Caswell and Williams 2007), indicating that P. multocida does not cause fibrin exudation on pleural and pericardial cavities, which are typical lesions of Actinobacillus. pleuropneumoniae, Actinobacillus suis (A. suis) and/or H. parasuis infection, which were absent in the present study. However, our findings are in agreement with Ono et. al (2003), Pors et. al. (2011), Oliveira Filho et al. (2015) and Pors et al. (2016) who described septicemia, infection of extrapulmonary sites, as well as Cappuccio et al. (2004), Kich et al. (2007) and Oliveira Filho et al. (2015), who suggested P. multocida plays a primary role.

The only clinical sample without pneumonia was from a 22-week-old animal, which only had a marked fibrino-purulent polyserositis. In this case, it was possible to obtain a pure culture of $P$. multocida type A from all lesion sites except from the abdominal cavity, similar to the reports of Ono et al. (2003), Kich et al. (2007) and Oliveira Filho et al. (2015) in experimental inoculations.

Histologically, pulmonary alterations were within the expectations for $P$. multocida infection, with neutrophilic bronchopneumonia, which were associated with remarkable circulatory disorders such as edema and hemorrhage. These pathological changes were described by Pijoan (2006) and Caswell \& Williams (2007) in cases of P. multocida infection. However, there was marked fibrin exudation in alveolar, interlobular and subpleural spaces in 33 lung samples but with no difference between Groups (Table 2). No samples showed bacteriological growth nor histological lesions that would suggest the involvement of A. pleuropneumoniae or $A$. suis infection, in addition to the remarkable presence of fibrin, or that would suggest the presence of other agents (Caswell \& Williams 2007). These results corroborate the findings of Ono et al. (2003), Kich et al. (2007),
Hansen et al. (2010) and Pors et al (2011) who suggest the ability of $P$. multocida to induce fibrin exudation in the lung and pleura. Furthermore, bronchiectasis was observed in eleven samples, three with mixed infections of Mycoplasma hyopneumoniae, Influenza A virus and P. multocida, and two with Influenza A virus and P. multocida co-infection. Pijoan (2006) and Caswell \& Williams (2007) stated that this type of injury is often observed when there are mixed infections that lead to necrosis of the bronchi and bronchioles. However, four samples that were negative for PCV2, M. hyopneumoniae and Influenza A by IHC, with only P. multocida detected, also had bronchiectasis, either suggesting that (1) the above agents were no longer detectable, due to the timing of infection and testing sensitivity limitations, or that (2) P. multocida alone is capable of causing that type of lesion. From these four lung samples, only one had lesions in the chronic phase, strengthening the possibility of P. multocida alone being responsible for causing necrosis in the three that were still in the acute phase, as was also described by Pors et al. (2016).

Microscopic evaluation of mediastinal lymph nodes did not show marked histiocytic infiltration and/or lymphoid depletion, lesions suggestive of PCV2 infection. Therefore, these findings are consistent with the negative IHC results. Neutrophilic infiltration was observed in $39.4 \%$ and hemorrhage was observed in $24.2 \%$ of the lymph node samples, as expected for infection by P. multocida (Caswell \& Williams 2007). A single clinical sample had severe fibrin-hemorrhagic neutrophilic lymphadenitis, which tested positive only for P. multocida, suggesting that the hemorrhage and fibrin exudation may be related to this agent, as in cases of fibrinous pericarditis and pleuritis.

Table 3 show that the isolates from farm clinical specimens (Group A) are involved in a general framework of greater extent and intensity of lesions and that there is a numerical trend for the occurrence of pleuritis, pericarditis, cavitary liquid accumulation and lymphadenopathy in this group, with only detection of $P$. multocida. In the present study, a higher incidence of BALT hyperplasia in lung samples was seen in Group B $(P=0.0089)$. This lesion is observed in chronic cases associated with $M$. hyopneumoniae infection, and the samples in this group had a general pathological finding of a smaller affected area and less severe lesions. Of the 19 samples of Group B, nine had moderate BALT hyperplasia and were positive to $M$. hyopneumoniae by IHC at a moderate to severe level. Therefore, it can be suggested that these isolates of $P$. multocida from Group B are opportunistic strains, taking part in a previous infection of M. hyopneumoniae and/or Influenza A virus, as described in the literature (Pijoan 2006, Caswell \& Williams 2007, Hansen et. al. 2010).

The observations of this study suggest that $P$. multocida alone was associated with acute lesions in the pleura and pericardial sac, with marked exudation of fibrin at these sites, as well as in the pulmonary epithelium and mediastinal lymph node, associated with severe clinical condition and mortality (Group A). Additionally, there was one case of severe acute fibrinous pleuritis and pericarditis in Group A in the absence of pneumonia, with pure isolation 
of $P$. multocida from the injury sites and no identification of other agents. This animal was euthanized due to a severe respiratory disorder, high fever, cyanosis of hooves and nostrils and refusal to walk. These findings may suggest the involvement of highly pathogenic pleurotropic P. multocida strains that can change the pathological pattern of expected lesions related to this agent.

Antimicrobial sensitivity evaluation of bacterial isolates obtained from Group A showed a numerical trend of greater resistance towards Group A, as shown in Figure 3 what may suggest the circulation of more resistant strains involved in clinical cases, leading to serious illness and mortality, unlike those who reached slaughter age, despite the severe pulmonary lesions. In addition to showing more serious and extensive pathological alterations, these bacterial isolates also had a higher resistance rate to antimicrobial agents, which may suggest an evolutionary adaptation of these strains. Further studies of highly pathogenic isolates and their antimicrobial resistance should be performed in order to determine if there is a genetic marker that would support these findings. The sensitivity profile of pulmonary and extrapulmonary isolates showed the same pattern, since in four studied cases, two demonstrated a lower drug sensitivity profile for the isolates that were obtained from extrapulmonary regions compared to the isolates that were obtained from the respective lung. Hence this trend should be further investigated to understand if the extra pulmonary isolates demonstrate different profile of sensitivity, and its mechanisms.

The low sensitivity rate for penicillin and lincomycin is expected, as it is more recommended for Gram-positive bacteria (Spinosa et al. 2006). Among the fluoroquinolones, norfloxacin performed better and enrofloxacin and ciprofloxacin showed remarkable resistance rates, in agreement with the findings of Borowski et al. (2002) in Rio Grande do Sul but contradictory to Silva et al. (2009) in Mato Grosso. On the contrary, Morés et al. (2015) described a high resistance rate to Norfloxacin but not to enrofloxacin in samples from the southern region of the country. Spectinomycin had the second highest sensitivity rate, in agreement with Maciel et al. (2011) in Minas Gerais but contrary to Borowski et al. (2002) in Rio Grande do Sul. The extensive and inappropriate use of drugs in the field allows the selection of resistant strains, as well as leads to an inappropriate cost of medication. These findings highlight the importance of correctly determining the sensitivity profile to drugs used in each herd, to obtain a more technical and effective indication and rational use of antimicrobials in the swine industry.

Comparison among samples shows a general trend towards a more severe picture in clinical cases, with the occurrence of fibrinous pleuropneumonia and pericarditis. These animals were selected based on evident acute severe clinical respiratory signs, which in most cases would lead to death before they reached slaughter age. In thirteen samples, it was possible to detect the involvement of $P$. multocida alone, which may suggest its direct participation in the mortality of finishing pigs or that other agents would no longer be detected regarding a possible chronicity. Ho- wever, in twelve of these thirteen cases, the pulmonary alterations were still in an acute phase of inflammation, enhancing the probability of detecting other pathogens, such as Influenza A virus. Thus, the results of this study indicate that there is probably a difference inherent in this type of pathogenic strain that determines, for example, extended tissue damage, fibrin exudation, and systemic dissemination capacity, as reported by Pors et al. (2011), and also by Kich et al. (2007), Oliveira Filho et al. (2015) and Pors et al (2016) when experimentally succeeded in reproduce the clinical-pathological picture. Several researchers have used molecular techniques to compare isolates of $P$. multocida obtained from clinical cases and healthy animals. However, no conclusive results have been reported that would explain different clinical presentations (Borowski et al. 2002, Chen et al. 2002, Lainson et al. 2002, Davies et al. 2003, Bethe et al. 2009, Tang et al. 2009, Bisgaard et al. 2013).

Challenge trials using different clinical isolates associated with molecular techniques are of great value to better characterize. Nevertheless, researches performed so far could not determine the pathogenesis and its invasiveness mechanisms (Bethe et al. 2009, Pors et al. 2011). It is necessary to determine the unknown virulence factors that lead to more severe clinical conditions than those that are traditionally known and reported, and to establish a clonal relationship among strains obtained from field samples (Borowski et al. 2002, Boyce et al. 2010, Bisgaard et al. 2013). Davies et al. (2003) stated that outer membrane proteins exhibit heterogeneity among strains and that this may be a good marker to determine epidemiological relationships between them. However, little is known about these proteins, including their role in pathogenicity in the organism. Pors et. al (2011) reported high genetic diversity in Danish pneumonic cases, with a low number of sequence types and few clonal complexes, which indicates that there is a limited number of clones involved that could be unassociated with the type of histopathological lesion. These authors suggested that there are different clones of $P$. multocida involved in pulmonary cases or progressive atrophic rhinitis, but little is known about them, however Pors et al. (2016) demonstrated that different isolates inoculated in the same host specie in an experimental inoculation, could develop different clinical and pathological pictures.

Davies et al. (2003) suggested two theories regarding possible clinical-pathological manifestations of different strains of $P$. multocida. The first theory is that there is little genetic diversity among strains of $P$. multocida, as they represent the normal microbiota of the respiratory system of pigs that would be capable of causing clinical disease in predisposed animals. The other theory shows that samples originating from diseased animals would present less genetic diversity since a smaller number of clones would be capable of causing a primary disorder. Therefore, it is necessary to compare samples obtained from healthy animals or commensal strains with strains isolated from severely diseased animals and to then determine the genetic diversity among them. To our knowledge, no such study has been conducted but if the second theory is confirmed, the same authors stated that there is a possibility that $P$. 
multocida may behave as a primary agent, as supported in the present study. Therefore, it is of great importance to determine possible genetic markers to identify the cases of major pathogenicity found in Brazilian field samples with the involvement of $P$. multocida alone.

\section{CONCLUSIONS}

This study demonstrated the occurrence of acute fibrinous pleuropneumonia in finishing pigs associated with Pasteurella multocida alone in some cases, which may suggest its primary participation in the development of the pathological disease.

Lungs from sick pigs at the farm (clinical cases) showed more severe pathological findings, suggesting the involvement of more pathogenic strains of $P$. multocida.

It is very important to determine possible genetic markers to confirm that these cases of major pathogenicity that were found in field samples are due solely to P. multocida.

Acknowledgments.- The authors thank CAPES, CNPq and Fapemig for financial support. Also, the authors are grateful to Dr. Rodrigo O.S. Silva for the valuable technical support provided, and the veterinarians and producers that allowed sample collection at the farms. Guedes R.M.C. has a research fellowship from CNPq.

Conflict of interest statement.- The authors declare no conflicts of interest.

\section{REFERENCES}

Barbosa T.R., Costa A.T.R. \& Reis R. 2009. Frequência das infecções bacterianas associadas à Circovirose suína clínica. Proc. 14th Congresso da Associação Brasileira de Veterinários Especialistas em Suínos (ABRAVES), Belo Horizonte, MG.

Bauer A.W., Kirby W.M., Sherris J.C. \& Turck M. 1966. Antibiotic susceptibility testing by a standardized single disk method. Am. J. Clin. Pathol. 45(4):493-496.

Bethe A., Wieler L.H., Selbitz H. \& Ewers C. 2009. Genetic diversity of porcine $P$. multocida strains from the respiratory tract of healthy and diseased swine. Vet. Microbiol. 139:97-105.

Bisgaard M., Petersen A. \& Christensen H. 2013. Multilocus sequence analysis of Pasteurella multocida demonstrates a type species under development. Microbiology 159:580-590.

Borowski S.M. 2001. Pasteurelose pulmonar: uma atualização. Proc. Congresso Brasileiro de Veterinários Especialistas em Suínos, Embrapa Suínos e Aves, Concórdia, p.90-95.

Borowski S.M., Ikuta N., Lunge V., Fonseca A., Marques E. \& Cardoso M. 2002. Caracterização antigênica e fenotípica de cepas de Pasteurella multocida isoladas de pulmões de suínos com pneumonia e/ou pleurite. Pesq. Vet. Bras. 22(3):97-103.

Borowski S.M., Barcellos D.E.S.N. \& Morés N. 2007. Pasteurelose pulmonar, p.177-181. In: Sobestiansky J. \& Barcellos D.E.S.N. (Eds), Doença dos Suínos. Cânone Editorial, Goiânia.

Boyce J.D., Harper M., Wilkie I.W. \& Adler B. 2010. Pasteurella, p.325-346. In: Gyles C.L., Prescott J.F. \& Songer J. (Eds), Pathogenesis of Bacterial Infections in Animals. 4th ed. Blackwell Publishing, Ames.

Brentano L., Ciacci-Zanella J.R., Morés N. \& Piffer I. 2002. Levantamento soroepidemiológico para coronavírus respiratório e gastroenterite transmissível e dos vírus de influenza H3N2 e H1N1 em rebanhos suínos no Brasil. Comun. Téc. 306, Embrapa Suínos e Aves, Concórdia. <http://www.cnpsa.embrapa.br/sgc/sgc_publicacoes/cot306.pdf>

Cappuccio J., Leotta G.A., Vigo G., Moredo F., Wolcott M.J. \& Perfumo C.J. 2004. Phenotypic characterization of Pasteurella multocida strains isolated from pigs with broncho and pleuropneumonia. Proc. 18th Congress of the International Pig Veterinary Society, Hamburgo, p.205.
Carter G.R. \& Rundell S.W. 1975. Identification of type A strains of P. multocida using Staphylococcal hyaluronidase. Vet. Rec. 96(15):343.

Carter G.R. \& Subronto P. 1973. Identification of type D strains of Pasteurella multocida with acriflavine. Am. J. Vet. Res. 34(2):293-294.

Castro L.A. 2008. 0 sequenciamento do genoma de Mycoplasma hyopneumoniae e sua repercussão na suinocultura. Acta Scient. Vet. 36:101-105.

Castro L.A., Schuck D., Morés N., Zaha A., Ferreira H.B. \& Driemeier D. 2009. Monospecific polyclonal antibodies for immunodetection of Mycoplasma hyopneumoniae in swine pneumonic lungs. Vet. Immunol. Immunopathol. 128:336-337.

Caswell J.L. \& Williams K.J. 2007. Respiratory system, p.523-653. In: Jubb K.V.F., Kennedy P.C. \& Palmer N.C. (Eds), Pathology of Domestic Animals. 5th ed. Elsevier Saunders, Philadelphia.

Chen H.I., Hulten K. \& Clarridge III J.E. 2002. Taxonomic subgroups of Pasteurella multocida correlate with clinical presentation. J. Clin. Microbiol. 40(9):3438-3441.

Costa A.T.R., Reis R., Ferreira H.B.C. \& Martins E.M.S. 2009. Isolamento de Mycoplasma hyopneumoniae de pulmões no Brasil. Proc. 14th Congresso da Associação Brasileira de Veterinários Especialistas em Suínos, p.399400.

Costa A.T.R., Reis R. \& Moreno A. 2011. Caracterização de cepas de Pasteurella multocida isoladas de casos clínicos em suínos. Proc. 15th Congresso da Associação Brasileira de Veterinários Especialistas em Suínos (ABRAVES), Fortaleza, Ceará, p.10-11.

Davies R.L., MacCorquodale R., Baillie S. \& Caffrey B. 2003. Characterization and comparison of Pasteurella multocida strains associated with porcine pneumonia and atrophic rhinitis. J. Med. Microbiol. 52:59-67.

Fablet C., Marois C., Dorenlor V., Eono F., Eveno E., Jolly J.P., Devendec L.L., Kobish F., Madec F. \& Rose N. 2011. Bacterial pathogens associated with lung lesions in slaughter pigs from 125 herds. Res. Vet. Sci. 143(2/3):120-131.

Haines D.M., Waters E.H. \& Clark E.G. 1993. Immunohistochemical detection of swine influenza A virus in formalin-fixed and paraffin-embedded tissues. Can. J. Vet. Res. 57(1):33-36.

Halbur P.G., Paul P.S., Frey M.L., Landgraf J., Eernisse K., Meng X.J., Lum M.A., Andrews J.J. \& Rathje J.A. 1995. Comparison of the pathogenicity of two US porcine reproductive and respiratory syndrome virus isolates with that of the Lelystad virus. Vet. Pathol. 32:648-660.

Hansen M.S., Pors S.E., Jensen H.E., Bille-Hansen V., Bisgaard M., Flachs E.M. \& Nielsen O.L. 2010. An investigation of the pathology and pathogens associated with porcine respiratory disease complex in Denmark. J. Comp. Pathol. 143:120-131.

Heres T.S. 2009. Caracterização de amostras de Pasteurella multocida isoladas de lesões pneumônicas associadas ou não com Circovirose em suínos. Dissertação de Mestrado, Universidade Federal do Rio Grande do Sul, Porto Alegre.

Kich J.D., Morés N., Triques N.J., Nogueira M.G., Locatelli C., Klein C.S. \& Felicio R.P. 2007. P. multocida tipo A atuaria como agente primário nos processos pneumônicos dos suínos? Comun. Téc. 469, Embrapa Suínos e Aves, Concórdia. <www.cnpsa.embrapa.br/sgc/sgc_publicacoes/publicacao_x8g42b6i.pdf>

Kich J.D., Kuchishi S.S., Morés M.A.Z. \& Lara A.C. 2010. Agentes bacterianos de pneumonia associados à infecção por Mycoplasma hyopneumoniae. Proc. Simpósio Internacional de Suinocultura (Sinsui), Produção, Reprodução e Sanidade Suína, Porto Alegre, RS, p.17-25.

Kim J., Chung K. \& Chae C. 2003. Association of porcine Circovirus 2 with porcine respiratory disease complex. Vet. J. 166:251-256.

Lainson F.A., Aitchison K.D., Donachie W. \& Thomson J.R. 2002. Typing of Pasteurella multocida isolated from pigs with and without porcine dermatitis and nephropathy syndrome. J. Clin. Microbiol. 40(2):588-593.

Lichtensteiger C.A., Steenbergen S.M., Lee R.M., Polson D.D. \& Vimr E.R. 1996. Direct PCR analysis for toxigenic Pasteurella multocida. J. Clin. Microbiol. 34(12):3035-3039.

Luna L.G. 1968. Routine staining procedures, p.24-58. In: Luna L.G. (Ed.), Manual of Histologic Staining Methods of the Armed Forces Institute of Pathology. McGraw-Hill Book Co., New York. 
Maciel B.A.G., Brandão A.R. \& Moreira V.G. 2011. Avaliação da sensibilidade de agentes bacterianos frente a antimicrobianos em suínos com infecções respiratórias. Proc. 15th Congresso da Associação Brasileira de Veterinários Especialistas em Suínos (ABRAVES), Fortaleza, Ceará, p.12-13.

Mancini D.A.P., Cunha E.M.S. \& Mendonça R.M.Z. 2006. Evidence of swine respiratory infection by influenza viruses in Brazil. Virus Rev. Res. 11:39-43.

Morés M.A.Z. 2006. Anatomopatologia e bacteriologia de lesões pulmonares responsáveis por condenações de carcaças de suínos nos matadouros. Dissertação de Mestrado, Universidade Federal do Paraná, Curitiba.

Morés M.A.Z., Oliveira Filho J.X., Rebelatto R., Klein C.S., Barcellos D.E.N., Coldebella A. \& Morés N. 2015. Aspectos patológicos e microbiológicos das doenças respiratórias em suínos de terminação no Brasil. Pesq. Vet. Bras. 35(8):725-733.

Oliveira Filho J.X.. Morés M.A.Z., Rebelatto R., Agnol A.M.D., Plieski C.L.A., Klein C.S., Barcellos D.E.N. \& Morés N. 2015. Pasteurella multocida type $A$ as the primary agent of pneumonia and septicaemia in pigs. Pesq. Vet. Bras. 35(8):716-724.

Ono M., Okada M., Namimatsu T., Fujii S., Mukai T. \& Sakano T. 2003. Septicaemia and arthritis in pigs experimentally infected with Pasteurella multocida capsular serotype A. J. Comp. Pathol. 129(4):251-258.

Pijoan C. 2006. Pneumonic pasteurellosis, p.719-726. In: Straw B.E., Zimmerman J.J., D`Allaire S. \& Taylor D.J. (Eds), Diseases of Swine. 9th ed. Iowa State University Press, Ames.

Pors S.E., Hansen M.S., Bisgaard M. \& Jensen H.E. 2011. Ocurrence and associated lesions of Pasteurella multocida in porcine bronchopneumonia. Vet. Microbiol. 150(1/2):160-166.

Pors S.E., Hansen M.S., Bisgaard M., Jensen H.E. \& Iburg T.M. 2013. Immunohistochemical study of porcine lung lesions associated with Pasteurella multocida. Vet. J. 197(2):483-438.

Pors S.E., Chadfield M.S., Sorensen D.B., Offenberg H., Bisgaard M., Jensen
H.E. 2016. The origin of Pasteurella multocida impacts pathology and inflammation when assessed in a mouse model. Res. Vet. Sci. 105:139142.

Quinn P.J., Carter M.E. \& Markey B.K. 1994. Clinical Veterinary Microbiology. Wolfe Publishing, London, 648p.

Schaefer R., Ciacci-Zanella J.R., Brentano L., Vincent A.L., Ritterbusch G.A., Silveira S., Caron L. \& Morés N. 2011. Isolation and characterization of a pandemic H1N1 Influenza virus in pigs in Brazil. Pesq. Vet. Bras. 31(9):761-767.

Silva G.R.F., Silva M.C. \& Dias D.F. 2009. Surto de pneumonia por Pasteurella multocida em suínos no estado do Mato Grosso. Proc. 14th Congresso da Associação Brasileira de Veterinários Especialistas em Suínos (ABRAVES), Belo Horizonte, MG, p.407-408.

Spinosa H.S., Górniak S.L. \& Bernardi M.M. 2006. Farmacologia Aplicada à Medicina Veterinária. 4th ed. Ganabara Koogan, Rio de Janeiro, 897p.

Souza N.N., Lobato Z.I.P. \& Guedes R.M.C. 2008. Estudo retrospectivo de diagnósticos de Circovirose suína pela técnica de imunoistoquímica. Arqs Inst. Biológico, São Paulo, 75:521-525.

Tang X., Zhao Z., Hu J., Wu B., Cai X., He Q. \& Chen H. 2009. Isolation, antimicrobial resistance and virulence genes of Pasteurella multocida strains from swine in China. J. Clin. Microbiol. 47(4):951-958.

Townsend K.M., Boyce J.D., Chung J.Y., Frost A.J. \& Adler B. 2001. Genetic organization of Pasteurella multocida cap loci and development of a multiplex capsular PCR typing system. J. Clin. Microbiol. 39:924-929.

Vincent L.L., Janke B.H., Paul P.S. \& Halbur P.G. 1997. A monoclonal-antibody-based immunohistochemical method for the detection of swine influenza virus in formalin-fixed, paraffin-embedded tissues. J. Vet. Diagn. Invest. 9:191-195.

Wellenberg G.J., Bouwkamp F.T., Wolf P.J., Swart W.A., Mombarg M.J. \& de Gee A.L. 2010. A study on the severity and relevance of porcine circovirus type 2 infections in Dutch fattening pigs with respiratory diseases. Vet. Microbiol. 142(3/4):217-224. 